\title{
Freewriting Can Offset the EFL Students' Anxiety of Writing in English
}

\author{
Jui-Hua Chen, Ph.D
}

Department of Foreign Languages and Literature, National Sun Yat-Sen University, 70 Lienhai Rd., Kaohsiung 80424, Taiwan

DOI: $\frac{\text { 10.36348/jaep.2019.v03i12.004 }}{\text { | Received: 06.12.2019| Accepted: } 20.12 .2019 \mid \text { Published: } 23.12 .2019}$

*Corresponding author: Jui Hua Chen

\section{Abstract}

Freewriting is defined as timed writing without stopping and checking grammar, format, and structures, and has not only been used as a powerful tool for developing student writing in educational contexts but also as therapy. However, freewriting is often used in writers' first language and relatively less used in their second language. This article will, therefore, explore whether the benefits of freewriting will offset the anxiety of writing in a second language in EFL classes. It was conducted in a three-credit writing course designed to help students master effective English writing skills and strategies. Eighteen freshmen of the Department of Foreign Languages and Literatures were required to do freewriting in the first thirty minutes of each week for fifteen weeks and were asked to write a reflection on freewriting in the eighteenth week. Of the eighteen students, seventeen of them positively comment on freewriting practices and revealed some beneficial effect, which shows that freewriting can be a powerful teaching tool in English writing courses for EFL classes.

Keywords: Freewriting, EFL, writing anxiety, reflection.

Copyright @ 2019: This is an open-access article distributed under the terms of the Creative Commons Attribution license which permits unrestricted use, distribution, and reproduction in any medium for non-commercial use (NonCommercial, or CC-BY-NC) provided the original author and sources are credited.

\section{INTRODUCTION}

For most students in Taiwan, English is only a subject. They don't think English is a tool for communicating and expressing ideas, because from year 7, students practice English grammar exercises on a daily basis to cope with official high school and college entrance exams. The only purpose of learning English is to be able to answer the questions of the official entrance exams. Therefore, in order to get a high score, many teachers of English are somewhat over-reliant on teaching through the grammartranslation method and most students are trained to avoid using complex sentences and words to express their ideas. Grammar-oriented English language education in Taiwan leads students to be afraid to state their opinions in English because they worry about grammatical errors or lack of proper vocabulary.

Chen [1] observed that few people write effortlessly. Writing has been a difficult skill for students, especially EFL students, to learn and develop. They often struggled to transform their thoughts into words and put them on paper. Students are confused with word usage, sentence structure, and are constrained by a shortage of vocabulary, alternative expressions and cultural knowledge.
However, in university education, students often need to present their learning outcomes through writing. Therefore, having the ability to use writing to effectively convey ideas has become the key to success in university education [2-5]. Chen [1] added that writing is not only a communicative tool, but also a means of learning, organizing knowledge and thinking. Furthermore, English is used as the language of instruction in more and more courses in tertiary education in Taiwan. All teaching, exercise and practical materials are provided in English. Students are requested to sit the exam and submit their reports in English. Thus, conveying ideas in English has played a pivotal role in students' academic achievement in tertiary education. Additionally, Raimes [6] stated that it was important to remember that when teaching and monitoring writing activities, "we are not dealing with ESL but rather TSL: Thinking in a Second Language".

In Taiwan's higher education, teachers have an urgent task to change the rigid grammar-based operant learning behaviours learned in six-year (from year seven to year twelve) compulsory English language education. Rivers [7] claimed that at university, English language education should emphasize the ability to communicate and express yourself in various situations. In fact, students already have writing skills, but the development and implementation of these skills should 
be the focus of university English language education [7].

The idea of 'freewriting' proposed by Elbow [8] may change students' writing habits. Elbow [8] proposed that freewriting requires two skills: creating and criticizing. At the first stage, students write freely and uncritically, so they can generate as many words and ideas as possible without worrying about whether they are good. At the second stage, students need to criticize their own ideas and words, and they will take good ones and discard those unrelated or bad ones. Then, they can "shape what is left into something strong." (p.7)

Freewriting is defined as timed writing without stopping and checking grammar, format, and structures, and has not only been used as a powerful tool for developing student writing in educational contexts but also as therapy. However, freewriting is often used in writers' first language and relatively less used in their second language. This article will, therefore, explore whether the benefits of freewriting will offset the anxiety of writing in a second language in EFL classes. It was conducted in a three-credit writing course designed to help students master effective English writing skills and strategies. Eighteen freshmen of the Department of Foreign Languages and Literatures were required to do freewriting in the first thirty minutes of each week for fifteen weeks and were asked to write a reflection on freewriting in the eighteenth week. Of the eighteen students, seventeen of them positively comment on freewriting practices and revealed some beneficial effect, which shows that freewriting can be a powerful teaching tool in English writing courses for EFL classes.

\section{METHODS}

This study seeks to discover whether freewriting can reduce EFL students' anxiety of writing in English. In order to gain first-hand information about freewriting from students' perspectives, this study employs students' reflection as the analysis content.

\section{Participants}

Eighteen freshmen of the Department of Foreign Languages and Literatures of National Sun Yat-Sen University participated in this study. These students entered the Department of Foreign Languages and Literature through recruiting talents or official university entrance examinations. The department requires all students to complete compulsory English writing courses for six semesters and each course takes three credits. All the students have to attend the class for three hours each week for eighteen weeks. Students participating in this study are taking the second semester English writing course. Because they have taken a semester fo English writing class in the previous semester, they are not new to English writing classes in the university.

\section{METHODS}

Eighteen freshmen of the Department of Foreign Languages and Literatures of National Sun Yat-Sen University were required to do freewriting in the first thirty minutes of each week for fifteen weeks and were asked to write a reflection on freewriting in the eighteenth week. They did not do freewriting on the first, the ninth and the eighteenth week. The teacher introduced the course and announced all the rules about freewriting and the syllabus in the first week. The ninth week was the midterm exam week and the last week was the final exam week.

The announcement of how to do freewriting is as following:

For Students:

1. All the students should attend the class on time.

2. All the students should write on a piece of paper which was provided by the teacher.

3. All the students should start to write when the teacher sets the timer for 30 minutes.

4. All the students have to write continuously and as much as possible, focusing on content and ideas during the writing time.

5. All students need to pay no attention to grammar, spelling, neatness, or style.

6. All the students should not look up words in dictionaries. If they don't know a word in English, they can substitute the L1 word and look up the word later.

7. All the students should stop writing when the time is up.

8. All the students have to take a picture of the writing and upload the picture to the personal account of the cyber university system of National Sun Yat-Sen University.

9. Do not stop writing.

10. Do not chat with classmates.

For teachers:

11. Teacher should monitor the class to make sure on one is being distracted by old habits.

12. Teacher should not grade the students' writing.

13. Teacher should not comment on students' writing.

14. Teacher should only record the word count in each writing. 


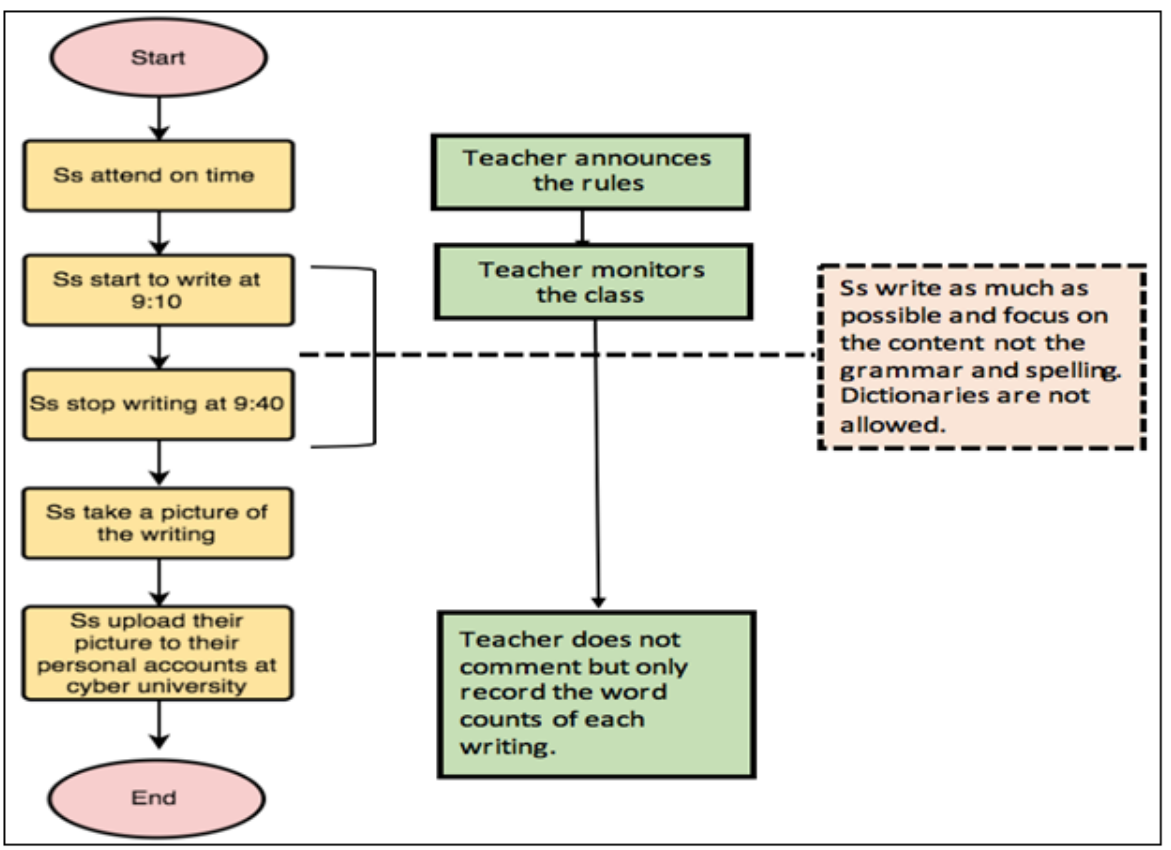

Fig-1: The process freewriting in each class

\section{Data Collection}

This qualitative study aims to explore whether freewriting, focusing only on content and not on grammar and spelling, can offset the students' writing anxiety in EFL classroom. Therefore, the data analysed in this article is the feedback from students of Department of Foreign Languages and Literature of National Sun Yat-Sen University in Taiwan after finishing doing fifteen-week freewriting activities in class. They were asked to write down their reflections on freewriting. In order to encourage students to truly express their thoughts on freewriting, they can choose to write in English or Chinese.

After collecting the reflection from the students, the teacher first divided the students' feedback into positive and negative categories; then, in order to faithfully present the students' thoughts on freewriting exercises, the teacher excerpted the students' representative ideas in this article.

Because students can choose to write the reflections in English or Chinese, in order for readers to understand the meaning of Chinese excerpts, the Chinese excerpts in this article will be translated into English. All translated versions have been read by the students themselves and confirmed that their content is the same as the original.

\section{FINDINGS AND DISCUSSION}

Students were asked to freely write any ideas about freewriting in Chinese or English in the eighteenth week of class. Of the eighteen students, nine chose to write in Chinese and the other nine wrote in English. Of the eighteen feedbacks collected, seventeen have positive reviews of freewriting, but only one has negative reviews. She felt that freewriting seems seemed useless to her.

Sixteen of the eighteen students said that freewriting allowed them to record life trivia, relieve stress, and find inspiration. Some students even think that because there are no restrictions on the topic and the structure of doing freewriting, and they do not need to worry about choosing the wrong English words so that they can write freely without pressure and express their inner thoughts and write more words. They even felt surprised that they sometimes used English words that were never used in formal writing in composition class.

Seven students believe that freewriting not only allows them to "speak" freely, it also acts as a therapist. Some of them pointed out that they can sort out or organize their thoughts in their brains while they are writing freely. Some students say that after writing negative emotions through freewriting, they can be more relieved. In addition, some students think that college students' lives are very busy, and it is difficult to have time to share their feelings with others. Freewriting can play a role as a listener.

In order to present students' thoughts about freewriting, the statements of representative participants were excerpted based on several themes such as pressure, anxiety, and therapy in the following section.

\section{No or Less Pressure, Restriction, and Worry \\ Student 1 's report \\ 這幾週自由書寫對我來說是一個很特別的 \\ 體驗，因為我從來沒有為了作業以外的事情寫過作 文, 連心情日誌都沒有。這次自由書寫的機會讓我}


可以在毫無壓力跟限制的情況下寫作, 能夠自由地 發會想像力, 運用文字傳達任何自己想說的話, 使 我重拾寫作的熱情。我發現寫作也是可以有樂趣的 。同時, 我發現在寫 freewriting 時反而使我更有靈 感, 有文思泉湧的感覺, 這是以前從來沒有過的感 覺。

Translation:

Doing freewriting in the past few weeks was a very special experience for me, because I had never written a composition for anything other than homework, and I didn't even keep a diary or write a journal. This opportunities of doing freewriting allowed me to write without pressure and restrictions, to freely express my imagination, to use words to convey whatever I wanted to say. I gained my passion for writing because writing can be fun, too. At the same time, I found that when I did freewriting, I was more inspired. I felt like a stream of thoughts. This was the feeling I had never had before.

\section{Student 2's report}

寫自由寫作的時候不用太在意文法, 也不 用像正式寫作一樣在意架構。真的能夠無拘束的抒 發, 少了平常寫作的暦力, 反而可以依照自己的喜 好去了解更多題材, 以及相關單字, 比起針對特定 題目下筆的生硬, 自由書寫真的自由多了, 也有趣 多了。

Translation:

When I do freewriting, I don't have to worry too much about grammar, and I don't have to worry about the structure as much as formal writing. I can really express my feelings freely, and reduce the pressure of writing. Instead, I can learn more about the subjects and related words according to my preferences. Compared with the bluntness of writing on specific topics, free writing is really more free and fun.

\section{Student 3's report}

Freewriting 對我來說是一件很放鬆的事, 因 為可以隨意寫下當時想的東西, 也不需要管單字和 文法的對錯。比起有指定題目的寫作, 我更喜歡 freewriting, 因為這樣可以寫出比較有創意的內容, 而且我從高中的時候就會用中文寫故事, 所以 freewriting 對我來說就是換一個語言寫故事而已。 我覺得可以沒有壓力的寫作是一件很棒的事情。

Translation:

Freewriting is a very relaxing thing for me, because I can write whatever I want at the time, and I don't need to worry about the words and grammar. I prefer freewriting to writing with specific topics, because I can write more creative content. And I have been writing stories in Chinese since high school, so for me freewriting is just writing a story in another language. I think writing without stress is a great thing.

\section{Student 5 's report}

我寫自己喜歡的內容就會越寫越多, 後來也 發現自己有進步, 對寫作也比較不害怕。䣱 freewriting 壓力就比較小, 不用怕寫不好, 也不用 給同學看。

Translation:

As I write my favourite content, I will write more and more words. I later found myself improving. I'm also less afraid of writing. Writing freewriting is less stressful. I don't have to worry about writing badly, and I don't have to show my composition to my classmates.

\section{Student 6's report}

Nowadays, most of the English teachers in high schools emphasize grammar and spelling too much, causing students to feel pressure when given an assignment on writing. Students would focus on how the sentences would appear rather than what ideas they want to convey. It is a pity that freewriting technique was introduced to us at college. If if could be introduced earlier, it would help a lot of students on writing. ...... The most wonderful advantage of freewriting is that we could choose any topic we like....... No restriction was needed to be considered.

\section{Student 7's report}

I think the freewriting we started this semester is a good way for us to write without being afraid of making mistakes and write more....... In this way, I can express myself more fluently in English.

\section{Student 8's report}

The freewriting we did this semester is indeed fun, without boundaries. It allows us to write freely as we like.....

\section{Student 9's report \\ 在這 30 分鐘裡, 我先讓自己放彭下來, 然 後開始將想法寫下來。因為沒有題目的限制, 沒有 文法的對錯, 我認為是一個能激發潛在想法的好工 具。}

Translation:

In these 30 minutes, I let myself relax, and then I started writing down ideas. Because there are no restrictions on the subject and there is no worry about grammar, I think it is a good tool to stimulate potential ideas.

\section{Student 10's report}


…… 其次是 freewriting 沒有主題, 所以不 必像寫其他作業一樣擔心文不對題。還有就是不用 顧慮文法上的錯誤。這樣就可以寫得比較自然輕鬆 。......我在寫 freewriting 時, 因為少了分數涯力也開 始慢慢享受寫作過程。

Translation:

..... The second is that freewriting has no topic, so you don't have to worry about the content you write is inconsistent or irrelevant with the title. There is no need to worry about grammatical errors. In this way, you can write more naturally and easily. ...... When I was writing freewriting, I began to enjoy the writing process gradually because there was no pressure to score....

\section{Student 11's report}

...... I realized that "writing is not something so limited in any form. I just poured in my life. Sometimes with the thoughts striking me at the moment. or the problems I had...

Student 12 's report

……雖然有時候只是寫一些廢話, 沒有什麼

意義的胡言亂語, 但是還是寫得很開心。最喜歡不 設限又不打分數的寫作了。

Translation:

....... Although sometimes I just write some nonsense, meaningless nonsense, but I still write very happily. I like writing without limits and scores.

Student 13 's report

我覺得 freewriting 是個幫助靈感抒發的方法 , 沒有對錯的考量, 就可以沒有壓力的書䳆。......當 我們可以毫無顧忌的書寫時, 心中的情緒也能比較 完整備表達。

Translation:

I think freewriting is a way to help express inspiration. Without right and wrong considerations, you can write without pressure. ... When we can write without fear, the emotions in our hearts can be more fully expressed.

\section{Student 18's report}

When I first began to write freewriting, it's really hard for me to write it out; however, it became easier and easier through weeks. I think it helps me become more familiar with writing. I also like the fact that freewriting doesn't need to be grammatical, because it makes students feel free to write.

\section{Writing as Therapy}

Student 8's report
Practicing freewriting not only helps me sharpen my writing skills, but also helps me sorting out thoughts in my brain, no matter it is about irrelevant stuff or serious matters.

\section{Student 12's Report}

就我來說, 我是個很容易把情緒憋在心理 的人, 寫 freewriting 就是給我一個抒發情緒的管道 。算是一個很棒的寫作療法。雖然有時候只是寫一 些廢話, 沒有什麼意義的胡言亂語, 但是還是寫得 很開心。最喜歡不設限又不打分數的寫作了。

Translation:

As far as I am concerned, I am a person who can easily trap emotions. Writing freewriting is a channel for expressing emotions. It's a great writing therapy. Although sometimes I just write some nonsense, meaningless nonsense, but I still write very happy. I like writing without limits and scores.

\section{Student 18's Report}

I make freewriting become my therapist. I always write my true feeling in it. Freewriting doesn't just help improve my writing, but also heal my mental. Freewriting is a very great opportunity for students to train their skills.

\section{CONCLUSION}

This study mainly explores whether the positive effects of EFL students' freewriting in English can offset the anxiety of English writing. According to students' experiences, more than $95 \%$ of students have a positive attitude towards freewriting in English. There are the following reasons: First, they can write whatever they want. Second, they don't need to focus on grammar and text structure. Third, students need not worry about using inappropriate English words. Therefore, this study finds that freewriting in English has made considerable value on EFL students' English writing class.

\section{RECOMMENDATIONS}

From the findings of this study, the following recommendations were made: The findings indicate that a large part of the EFL students' stress and pressure on English writing comes from grammar, text structure and words selections. Therefore, teacher can free students' from English writing anxiety through freewriting activities since students do not need to pay attention to grammar, spelling, neatness or style. Students will try out more of their ideas in such a risk free environment.

\section{REFERENCES}

1. Yueh-Miao, C. (2002). The problems of university EFL writing in Taiwan. The Korea TESOL Journal, Fall/Winter, South Korea, 5(1):59-80. 
2. Crème, P., \& Lea, M. R. (1997). Writing at the university: A guide for students. Buckingham: Open University Press.

3. Lee, M. R., \& Stierer, B. (Eds.) (2000). Student writing in higher education: New context. Buckingham: The Society for Research into Higher Education \& Open University Press.

4. Segall, M., \& Smart, R. A. (Eds.) (2005). Direct from the discipline: Writing across the curriculum. Portsmouth, NH: Boynton/Cook Publishers, Inc.

5. Li, L. Y. (2007). Exploring the Use of Focused Free Writing in Developing Academic Writing.
Journal of University Teaching and Learning Practice, 4(1):40-53. University of Canberra. http://ro.uow.edu.au/jutlp/vol4/iss1/5/

6. Raimes, A. (1985). What unskilled writers do as they write: A classroom study of composing. TESOL Quarterly, 19(2):229-258.

7. Rivers, J. D. (2007). Free-writing as an Expressive Communication Tool for Japanese English Learners. The Language Teacher, 31(11):9-12.

8. Elbow, P. (1989). Toward a phenomenology of freewriting. Journal of Basic Writing, 8 (2):42-71. 